\title{
COVID-19 DAN BIMBINGAN BELAJAR MASA PANDEMI DI DESA KERAMAT KECAMATAN AMUNTAI SELATAN
}

\author{
Haji Hamli, Mariatul Kibtiah, Maulana Hidayah, Sariyati, Sawitri, Siti Rahmah, \\ Widia \\ Sekolah Tinggi Ilmu Alquran (STIQ) Amuntai, Kalimantan Selatan, Indonesia \\ hajihamli0204@gmail.com, mkibtiah6@gmail.com, maulanahidayah5@gmail.com, \\ sarisariyati459@gmail.com, saresu28101999@gmail.com, \\ rahmahakim75@gmail.com, widiasalsa98@gmail.com
}

\begin{abstract}
ABSTRAK
Belajar dari rumah secara daring merupakan salah atu kebijakan pemerintah kitadi Indonesia selama masa pandemi Covid-19 ini, sehingga dalam mendampingi anak harus melibatkan banyak peran dari orang tua anak masing-masing.. Namun tidak semua orang tua bisa mendampingi anaknya dengan baik, karena masing-masing dari mereka mempunyai latar belakang tidak sama, sebagian besar orang tua di Desa Keramat merupakan seorang pekerja seperti swasta, petani, pedagang, pengrajin, buruh, dan sebagainya. Hal ini membuat pendampingan belajar terhadap anak menjadi tidak maksimal. Penelitian ini bertujuan agar mengetahui Covid-19 serta pendampingan belajar masa pandemi di Desa Keramat Amuntai Selatan Kabupaten Hulu Sungai Utara yang dilakukan oleh mahasiswa KKN STIQ Amuntai. Metode yang digunakan peneliti dengan menggunakan metode kualitatif dan jenis penelitiannya adalah menggunakan jenis penelitian studi kasus serta prosedur yang digunakan dalam mengumpulkan data adalah observasi, wawancara, dan dokumentasi. Subjek penelitian ini adalah para anak-anak Desa Keramat. Hasil dari penelitian adalah menyatakan bahwa pendampingan pembelajaran sesuatu yang sangat penting pada masa pandemi khususnya bagi anakanak di Desa Keramat. Dimana terlihat dari hasil kuesioner wawancara yang dilakukan kepada anakanak mengenai bimbingan belajar masa pandemi di Desa Keramat Kabupaten Hulu Sungai Utara diketahui oleh jawaban dari 10 responden dengan jawaban Ya rata-rata 0,85\%, dan jawaban responden Tidak rata-rata sebesar 0,15\%. Adanya pendampingan belajar ini memberi dampak positif kepada anak-anak, karena dapat belajar secara langsung atau tatap muka walaupun melalui pendampingan Mahasiswa Kuliah Kerja Nyata (KKN) STIQ Amuntai. Penelitian ini berkontribusi untuk meningkatkan minat anak-anak Desa Keramat dalam melakukan pembelajaran di rumah pada masa pandemi Covid-19.
\end{abstract}

Kata kunci: bimbingan belajar; belajar daring; covid-19

\section{PENDAHULUAN}

Saat di dunia sedang marak-maraknya wabah pandemi corona virus. (Aji Fatma Dewi, 2020) Krisis kesehatan yang pertama dan terutama di dunia sekarang ini adalah pandemic covid-19. Pandemi covid-19 ini sangat berdampak sekali bahakan sudah masuk ke dunia pembelajaran, Seluruh lembaga pendidikan diliburkan oleh pemerintahan baik dari pusat sampai ke daerah-daerah. Liburnya lembaga pendidikan merupakan upaya pemerintah agar virus corona tidak menyebar meluas. Diharapkan dengan Dihimbau agar seluruh lembaga pendidikan tidak melakukan kegiatan pembelajaran seperti biasa, agar dapat menurangi penyebar virus covid-19 ini. (Purwanto, et al 2020)

Berdasarkan Surat Edaran (SE) yang dikeluarkan pemerintah pada 18 Maret 2020, maka segala kegiatan di dalam dan di luar ruangan di semua sektor sementara waktu ditunda demi mengurangi penyebaran corona terutama pada bidang pendidikan.

Pada tanggal 24 Maret 2020 Menteri Pendidikan dan Kebudayaan Republik Indonesia mengeluarkan Surat Edaran Nomor 4 Tahun 2020 Tentang Pelaksanaan Kebijakan Pendidikan Dalam Masa Darurat Penyebaran Covid-19. Surat Edaran 
tersebut menjelaskan bahwa proses belajar dilaksanakan di rumah melalui pembelajaran daring. (Satiyasih Rosali, 2020) Pembelajaran daring merupakan pembelajaran yang dilakukan dalam jaringan seperti melalui konferensi video, di mana guru dan siswa yang berada di tempat yang berbeda dapat berbagi video, suara, teks, file dari layar komputer atau handphone.

Pembelajaran daring dalam pelaksanaannya secara umum memiliki beberapa faktor penghambat, diantaranya yaitu kurangnya fasilitas yang mendukung untuk belajar daring seperti kepemilikan media belajar (HP), kouta internet yang tidak memadai, kurangnya pendampimgan belajar dari orang tua (orang tua memiliki HP tetapi orang tua bekerja seharian di luar rumah sehingga orang tua hanya dapat mendampingi ketika malam hari), kurangnya pengetahuan orangtua mengenai penggunaan teknologi selama mendampingi anak belajar, dan fitur HP yang terbatas. ${ }^{2}$ Selain itu, hambatan yang dialami orang tua dalam mendampingi anak belajar di rumah meliputi kurangnya pemahaman materi oleh orang tua, kesulitan orang tua dalam menumbuhkan minat belajar anak, tidak memiliki waktu untuk mendampingi anak karena harus bekerja, orang tua tidak sabar dalam mendampingi anak saat belajar di rumah, dan kesulitan orang tua dalam mengoperasikan HP. ${ }^{3}$

Berdasarkan observasi yang kami lakukan, ditemukan bahwa hambatan pembelajaran daring yang ditemukan pada anak-anak Desa Keramat yaitu sulitnya anak-anak memahami pelajaran dan pendampingan belajar yang tidak maksimal karena adanya orang tua yang tidak paham dengan penggunaan handphone, banyaknya orangtua pekerja dan kesulitan memahami materi pelajaran, sehingga sulit untuk mendampingi anak ketika proses belajar mengajar. Melihat kondisi ini, mahasiswa KKN berinisiatif mengadakan program bimbingan belajar untuk anakanak Desa Keramat. Melalui program bimbingan belajar ini, maka diharapkan anak (siswa) dan orang tua dapat memperoleh manfaat, edukasi, dan pembimbingan selama proses pembelajaran ini. Hal ini sangat penting dilakukan mengingat banyaknya siswa yang malas-malasan selama pembelajaran daring dan banyak dari mereka yang menyalahgunkan penggunaan smartphone sebagai media pembelajaran. Melalui permasalahan ini maka diperlukan suatu pendampingan atau bimbingan belajar bagi siswa agar transfer ilmu dan pengembangan karakter selama masa pandemi ini dapat berjalan dengan baik. Dari permasalahan tersebut, maka peneliti tertarik untuk meneliti "Covid-19 dan Bimbingan Belajar Masa Pandemi di Desa Keramat Kecamatan Amuntai Selatan"

\section{METODE PENELITIAN}

Pendekatan yang peneliti gunakan dalam penelitian ini pendekatan kualitatif, Pendekatan Kualitatif adalah berusaha menemukan dan menggambarkan secara naratif kegiatan yang dilakukan. (Anggito dan Setiawan, 2018). Penelitian kualitatif

\footnotetext{
${ }^{1}$ Hamdan Husein Batubara, Pembelajaran Berbasis Web dengan Moodle Versi 3.4 (Yogyakarta: Deepublish, 2018), h. 151.

${ }^{2}$ Andri Anugrahana, "Hambatan, Solusi dan Harapan: Pembelajaran Daring Selama Masa Pandemi Covid-19 oleh Guru Sekolah Dasar," Scholaria: Jurnal Pendidikan dan Kebudayaan Vol. 10, no. 3 (2020): h. 286.

${ }^{3}$ Anita Wardani dan Yulia Ayriza, "Analisis Kendala Orang Tua dalam Mendampingi Anak Belajar di Rumah pada Masa Pandemi Covid-19," Jurnal Obsesi: Jurnal Pendidikan Anak Usia Dini Vol. 5, no. 1 (2021): h. 774.
} 
adalah prosedur penelitian yang menghasilkan data berupa ucapan, tulisan dan perilaku dari orang-orang yang diamati. (Nugrahani, 2014). Peneliti menggunakan jenis penelitian studi kasus yaitu jenis penelitian kualitatif secara mendalam tentang individu, kelompok, institusi, dan sebagainya dalam waktu tertentu. Tujuan dari jenis penelitian ini adalah berusaha menemukan makna, menyelidiki proses, serta memperoleh pengertian dan pemahaman yang mendalam secara utuh dari individu, kelompok atau situasi tertentu. (Sugiarto, 2015)

Dalam megumpulkan data peneliti menggunakan teknik wawancara mendalam, observasi partisipatif dan dokumentasi. Sebelum melakukan penelitian, terlebih dahulu peneliti menentukan apa subjek dan objek penelitian tersebut. Subjek yang ditentukan peneliti yaitu anak-anak serta orang tua Desa Keramat, sedangkan objeknya adalah pendampingan belajar masa pandemi. Data dikumpulkan sebagai upaya yang dilakukan untuk menghimpun informasi yang relevan dengan topik atau masalah yang akan atau sedang diteliti. (Hamzah, 2019) Sedangkan susunan langkah atau prosedur pengumpulan data yang dilakukan dalam penelitian ini yaitu melakukan observasi, wawancara, dan dokumentasi. ${ }^{4}$. Observasi merupakan salah satu dasar fundamental dari semua metode pengumpulan data dalam penelitian kualitatif, khususnya menyangkut ilmu-ilmu sosial dan perilaku manusia. (Hasanah, 2016) Observasi (observation) atau pengamatan merupakan suatu teknik mengumpulkan data dengan jalan mengadakan pengamatan terhadap kegiatan yang sedang berlangsung. Kegiatan tersebut bisa berkenaan dengan cara guru mengajar, siswa belajar, kepala sekolah yang sedang memberikan pengarahan, personil bidang kepegawaian yang sedang rapat, dan sebagainya. (Hardani, et.al 2020) Observasi dapat dilakukan secara partisipatif ataupun non-partisipatif. Dalam observasi partisipatif (participatory observation) pengamat ikut serta dalam kegiatan yang sedang berlangsung ditandai dengan ketersediaan format yang rinci dalam pelaksanaan pengamatan. 5 Sedangkan dalam observasi non-partisipatif (nonparticipatory observation) pengamat tidak ikut serta dalam kegiatan, dia hanya berperan mengamati kegiatan, tidak ikut dalam kegiatan. (Hardani, et.al 2020) Pada penelitian ini, peneliti menggunakan metode observasi non-partisipatif, yang mana peneliti hanya sebagai pengamat independen.

Wawancara adalah tanya jawab lisan antara dua orang atau lebih secara langsung atau percakapan dengan maksud tertentu. (Hardani, et.al 2020) Wawancara (interview) merupakan salah satu cara pengambilan data yang dilakukan melalui kegiatan komunikasi lisan dalam bentuk terstruktur, semi terstruktur dan tak terstruktur. (Harahap, 2020) Steward dan cash mendefinisikan sebagai sebuah proses komunikasi dyad (interpersonal) dengan tujuan yang telah ditentukan sebelumnya, bersifat serius yang dirancang agar tercipta interaksi yang melibatkan aktifitas bertanya dan menjawab pertanyaan. (Hakim, 2013) Dalam penelitian ini, peneliti menggunakan wawancara bentuk semi terstruktur. Jenis wawancara ini termasuk dalam kategori in-dept interview, di mana dalam pelaksanaannya lebih bebas bila dibandingkan dengan wawancara terstruktur. (Sugiyono, 2018). Dari segi terminologi

\footnotetext{
${ }^{4}$ I Wayan Suwandra, Metodologi Penelitian Kualitatif dalam Ilmu Sosial, Pendidikan Kebudayaan dan Keagamaan (Bandung: Nilacakra, 2018).

${ }^{5}$ Yulianti Kurnianingtyas Lorentya, "Implementasi Strategi Pembelajaran Kooperatif Teknik Jingsaw untuk Meningkatkan Keaktifan Belajar Akutansi pada Siswa Kelas X Akuntansi 3 SMK Negeri Yogyakarta Tahun Ajaran 2011/2012," Jurnal Pendidikan Akuntasi Indonesia Vol. X, no. No. 1 (2012): h. 70.
} 
dokumen sebagai kata kerja yang berarti bukti untuk memberikan kejelasan. ${ }^{6}$ Dokumen juga diartikan sebagai catatan peristiwa yang sudah berlalu. Dokumen bisa berbentuk tulisan, gambar, atau karya-karya monumental dari seseorang. (Sugiyono, 2018) Teknik pengumpulan data dengan dokumentasi ialah pengambilan data yang diperoleh melalui dokumen-dokumen. (Hardani, 2020)

Analisis data adalah mencari dan menyusun secara sistematis data yang diperoleh dari hasil wawancara, catatan lapangan dan dokumentasi, dengan cara mengorganisasikan data ke dalam kategori, menjabarkan ke dalam unit-unit, melakukan sintesa, menyusun ke dalam pola, memilih mana yang penting dan yang akan dipelajari, dan membuat kesimpulan sehingga mudah dipahami oleh diri sendiri maupun orang lain. (Sugiyono, 2018). Teknis analisis data dalam penelitian kualitatif adalah proses pengumpulan data serta mencari pola atau tema untuk memahami maknanya. (Suwandra, 2018) Dilihat dari segi penelitian kualitatif, teknik analisis data pada tahap ini terdiri dari tiga tahapan yakni mereduksi data, penyajian data, dan penarikan kesimpulan. Mereduksi data berarti merangkum, memilih hal-hal yang pokok, memfokuskan pada hal-hal yang penting, dicari tema dan polanya. (Sugiyono, 2018) Selanjutnya adalah penyajian data, yaitu sekumpulan informasi tersusun yang memberi kemungkinan adanya penarikan simpulan dan pengambilan tindakan. Penyajian yang paling sering digunakan pada data kualitatif pada masa yang lalu adalah bentuk teks naratif. Dalam penelitian kualitatif, penyajian data bisa dilakukan dalam bentuk uraian singkat, bagan, hubungan antar kategori, flowcard dan sejenisnya. (Hardani, et.al, 2020) Langkah ketiga menarik kesimpulan, hasil awal yang dicapai dalam penelitian ini masih tentatif, dan oleh karena itu jika tidak ada bukti kuat atau dukungan realistis. Dapat berubah sewaktu-waktu. Namun apabila kesimpulan yang dicapai didukung oleh bukti yang kuat dan konsisten, maka hasil data yang dicapai bersifat fleksibel. Temuan penelitian ini dapat memberikan penemuan baru yang sebelumnya tidak ada dalam bidang keilmuan. (Ritonga, Nazir, dan Wahyuni, 2020)

Pengecekan keabsahan data pada penelitian ini menggunakan teknik triangulasi. Triangulasi merupakan teknik pengumpulan data yang bersifat menggabungkan dari berbagai teknik pengumpulan data dan sumber data yang ada. Bila peneliti melakukan pengumpulan data dengan triangulasi, maka sebenarnya peneliti mengumpulkan data yang sekaligus menguji kredibiltas data, yaitu mengecek kredibilitas data dengan berbagai teknik pengumpulan data dan sumber data. Triangulasi teknik berarti peneliti menggunakan teknik pengumpulan data yang berbeda-beda untuk mendapatkan data dari sumber yang sama. (Sugiyono, 2018). Dengan kata lain bahwa dengan triangulasi, peneliti dapat me-recheck temuannya dengan jalan membandingkannya dengan berbagai sumber, metode, dan teori. (Moleong, 2007).

\section{HASIL DAN PEMBAHASAN}

\section{Pendampingan Belajar Masa Pandemi Covid-19 di Desa Keramat}

Kemunculan Covid-19 memberikan dampak bagi segala sektor, mulai dari perekonomian, pariwisata, dan pendidikan. Dari sektor pendidikan, semua aktivitas yang dilakukan di sekolah harus ditinggalkan dan diganti dengan dilakukan di rumah

${ }^{6}$ Dian Novita Fitriani, “Kajian Tentang Oral Dokument: Tinjauan Pada Gerakan Dokumentalis Baru," Visi Pustaka Vol. 20, no. No. 01 (2018): h. 25. 
secara daring (dalam jaringan). Program belajar dari rumah dilaksanakan secara mandiri di rumah masing-masing. Adanya kebijakan tersebut membuat orangtua kembali lagi menguatkan perannya untuk menjadi pendidik pertama dan utama bagi anak. (Suhanadji, dkk., 2021) Namun, tidak semua yang telah direncanakan akan berjalan lancar, tentu terdapat beberapa permasalahan yang menyulitkan pelaksanaan belajar secara daring tersebut, baik bagi pihak tenaga pendidik maupun anak dan orangtua.

Pemerintah melakukan kebijakan agar belajar dari rumah selama masa pandemi Covid-19 ini sehingga orang tua anak semakin banyak menggunakan waktunya dalam pendampingan anak-anak mereka masing-masing.. Namun hal tersebut tidak berjalan dengan lancer dan baik sesuai dengan rencana yang dibuat, dan tidak menghasilkan tujuan yang ingin dicapai. Macam-macam usaha yang dilakuakan agar problem atau masalah pendidikan teratasi, yaitu dengan cara melakukan pendampingan belajar sebagai bentuk pengabdian terhadap masyarakat.

Pendampingan belajar atau bimbingan belajar merupakan suatu bentuk kegiatan dalam proses belajar yang dilakukan oleh seseorang yang telah memiliki kemampuan lebih dalam banyak hal untuk diberikan kepada orang lain yang mana bertujuan agar orang lain dapat menemukan pengetahuan baru yang belum dimilikinya serta dapat diterapkan dalam kehidupannya.

Pendampingan belajar merupakan kegiatan pembelajaran anak-anak secarai bimbingan belajar. Bimbingan belajar adalah suatu pembelajaran anak dengan proses memberikan pertolongan atau bantuan belajar, baik untuk perorangan atau individu maupun orang banyak atau perkelompok oleh seseorang atau lebih dari seorang pembimbing yang mempunyai suatu keahlian pada bidang tersebut dalam menentukan pilihan, penyesuaian serta pemecahan problem atau masalah dalam belajar yang berkaitan dengan perubahan tingkah laku sebagai akibat dari pengalaman, rangsangan maupun latihan. Pendampingan dalam belajar melalui proses kegiatan bimbingan belajar dapat meningkatkan prestasi serta menambah motivasi belajar anak. Zumaroh menyatakan dalam penelitiannya bahwa motivasi belajar siswa underachiever dapat ditingkatkan melalui layanan bimbingan kelompok yang tepat. ${ }^{8}$. Hal ini lah yang memotivasi mahasiswa KKN STIQ untuk berinisiatif mengadakan program bimbingan belajar yang tujuannya untuk membantu dan memudahkan anak-anak di Desa Keramat dalam belajar secara online atau daring.

\section{Hasil Kuesioner Wawancara Semi Terstruktur Beserta Jawabannya}

Tabel 1. Kuesioner wawancara semi terstruktur kepada anak-anak mengenai bimbingan belajar masa pandemi di Desa Keramat

\begin{tabular}{|c|c|c|c|}
\hline \multirow[t]{2}{*}{ No } & \multirow[t]{2}{*}{ Pertanyaan } & \multicolumn{2}{|c|}{ Jawaban anak } \\
\hline & & Ya & Tidak \\
\hline 1. & Apakah belajar daring sangat sulit untuk diikuti? & 7 & 3 \\
\hline
\end{tabular}

\footnotetext{
${ }^{7}$ Siti Aisyah, Perkembangan Peserta Didik dan Bimbingan Belajar (Yogyakarta: Deepublish, 2015), 69.

${ }^{8}$ Agus Santoso dan Yunni Rusmawati, "Pendampingan Belajar Siswa di Rumah Melalui Kegiatan Bimbingan Belajar di Desa Guci Karanggeneng Lamongan," Abdimas Berdaya: Jurnal Pengabdian Masyarakat Vol. 2, no. 2 (2019): 38.
} 


\begin{tabular}{|c|c|c|c|}
\hline 2. & $\begin{array}{l}\text { Apakah penyampaian materi secara daring sukar } \\
\text { dipahami? }\end{array}$ & 8 & 2 \\
\hline 3. & $\begin{array}{l}\text { Apakah selama belajar daring banyak tugas } \\
\text { sekolah? }\end{array}$ & 10 & - \\
\hline 4. & $\begin{array}{l}\text { Apakah belajar daring merupakan cara terbaik } \\
\text { untuk belajar masa pandemi? }\end{array}$ & 5 & 5 \\
\hline 5. & Apakah fasilitas belajar daring memadai? & 8 & 2 \\
\hline 6. & $\begin{array}{l}\text { Apakah dengan adanya bimbingan belajar dari } \\
\text { mahasiswa KKN STIQ memudahkan dalam } \\
\text { belajar daring? }\end{array}$ & 10 & - \\
\hline 7. & $\begin{array}{l}\text { Apakah dengan adanya bimbingan belajar dari } \\
\text { mahasiswa KKN STIQ dapat membantu dalam } \\
\text { memahami pelajaran yang diberikan guru secara } \\
\text { daring? }\end{array}$ & 10 & - \\
\hline 8. & $\begin{array}{l}\text { Apakah dengan adanya bimbingan belajar dari } \\
\text { mahasiswa KKN STIQ dapat meringankan } \\
\text { beban tugas yang diberikan guru secara daring? }\end{array}$ & 10 & - \\
\hline 9. & $\begin{array}{l}\text { Apakah pendampingan belajar dari mahasiswa } \\
\text { KKN STIQ memberikan dampak positif? }\end{array}$ & 10 & - \\
\hline 10. & $\begin{array}{l}\text { Apakah dengan adanya bimbingan belajar dari } \\
\text { mahasiswa KKN STIQ dapat memotivasi anak } \\
\text { agar rajin belajar? }\end{array}$ & 7 & 3 \\
\hline \multicolumn{2}{|c|}{ Jumlah } & 85 & 15 \\
\hline
\end{tabular}

Berdasarkan data tabel dari Kuesioner wawancara semi terstruktur kepada anak-anak mengenai bimbingan belajar pada masa pandemi di Desa Keramat Kabupaten Hulu Sungai Utara diatas dapat kita ketahui bahwa jawaban dari 10 responden memberikan jawaban Ya dengan rata-rata sebesar $0,85 \%$, dan responden lain yang menjawab Tidak dengan rata-rata sebesar $0,15 \%$, hal ini dapat diambil kesimpulan bahwa penting adanya pendampingan bagi anak selama belajar daring masa pandemi covid-19 di Desa Keramat berupa bimbingan belajar. Agar anak termotivasi untuk rajin belajar dan memudahkan anak memahami pembelajaran secara daring serta mudah mengerjakan tugas yang diberikan oleh guru di sekolah mereka secara online atau daring.

\section{Faktor Penghambat Bimbingan Belajar Masa Pandemi di Desa Keramat}

Kegiatan bimbingan belajar yang diikuti oleh para siswa disebabkan oleh beberapa faktor. Kedekatan tempat tinggal mrupakan faktor geografis menjadi prioritas dan metode bimbingan juga merupakan faktor lainnya menjadi hal yang utama. dan Selain itu, faktor biaya kegiatan pada tiap daerah juga merupakan factor yang sangat penting. Selain faktor tersebut, menurut Eriany, mengikuti program bimbel banyak dipengaruhi oleh faktor motivasi intrinsik, yaitu sebesar 89.12\%. Besarnya faktor tersebut ada kemungkinan disebabkan oleh adanya rasa ketakutan menghadapi ujian, kurang adanya rasa percaya diri, serta harapan yang tinggi untuk diterima ditingkat pendidikan yang lebih tinggi. Lembaga bimbingan 
belajar di luar sekolah menjadi alternatif para siswa untuk mendapatkan materi yang belum diajarkan disekolah. ${ }^{9}$

Orang tua adalah orang yang paling sering bertemu dengan anak mereka, jadi pendampingan orang tua sangat perlu sekali ketika anak belajar dari rumah dibutuhkan sebagai koordinasi guru dengan orang tua anak. Orangtua seyogyanya mengajarkan kepada anak tentang cara mengatasi permasalahannya sendiri. Beberapa karakteristik pembelajaran daring diantaranya: constuctivism, social constructivism, community of learners, virtual class, dan perilaku interaktivitas, kemandirian, aksesibilitas serta pengayaan. ${ }^{10}$

Seiring diberlakukannya sistem pembelajaran daring dari rumah bermunculanlah berbagai macam masalah, diantaranya kurangnya pemahaman anak terhadap materi pembelajaran yang telah diajarkan guru. Maslah ini disebabkan oleh berbagai macam faktor di antaranya adalah kurangnya kemandirian anak dalam belajar, orang tua belum siap dalam membimbing dan mendampingi anak merka ketika belajar di rumah mereka, serta ketidaknyamanan akibat penggunaan gawai untuk belajar dalam waktu yang lama. Dalam hal ini, yang paling berperan penting untuk mengawasi dan memberikan faslitas dalam proses belajar anak adalah orang tua. Dan pengawasan belajar anak dirumah dengan berbagai alasan, di antaranya adalah tuntutan pekerjaan yang harus dilakukan baik di luar maupun di dalam rumah, kurangnya ilmu pengetahuan dan pengalaman orang tua dalam menolong atau membantu anaknya untuk memahami bahan materi yang diberikan oleh guru, dan kurangnya kesadaran orang tua agar membimbing anak mereka belajar dari rumah. Selain itu, terdapat juga beberapa orang tua yang tidak memiliki ponsel pintar karena faktor ekonomi sehingga tidak bisa membantu anaknya untuk mengikuti pembelajaran daring. Tentunya, keadaan ini akan mengakibatkan tujuan pembelajaran tidak tercapai secara maksimal. ${ }^{11}$

\section{Peran Mahasiswa KKN STIQ Pada Bimbingan Belajar Anak}

\section{Membantu Anak dalam Pembelajaran Online (Daring)}

Program Mahasiswa KKN STIQ Amuntai dalam bimbingan belajar bagi anak sekolah di Desa Keramat. Bimbingan belajar ini adalah salah satu dari program kerja wajib mahasiswa yang bertujuan untuk membantu para anak dalam belajar di masa pandemi seperti sekarang ini, sistem telah berubah mematuhi aturan pemerintah tentang pembatasan sosial. Sistem pembelajaran yang asalnya system tatap muka berubah menjadi sistem daring dari rumah atau online. Siswa banyak mendapatkan kesulitan dalam pembelajaran berbasis online atau daring ini. Terutama ketika mereka mengerjakan tugas yang telah diberikan oleh guru maupun tentang bahan materi yang diberikan terutama bagi para anak SD/MI/SMP/MTs. Oleh sebab itu, dalam memecahakan masalah kesulitan anak tersebut mahasiswa KKN STIQ melakukan bimbingan belajar di posko KKN, dengan mempersilahkan mereka untuk belajar

\footnotetext{
${ }^{9}$ Santoso dan Rusmawati, 38.

${ }^{10}$ Suhanadji dkk., "Keterlibatan Orangtua dalam Pendampingan Belajar Anak selama Masa Pandemi Covid-19," Jurnal Obsesi: Jurnal Pendidikan Anak Usia Dini Vol. 5, no. 2 (2021): 1142.

${ }^{11}$ Tri Handayani, Hariyani Nur Khasanah, dan Rolisda Yosintha, "Pendampingan Belajar di Rumah Bagi Siswa Sekolah Dasar Terdampak Covid-19," Abdipraja: Jurnal Pengabdian Kepada Masyarakat Vol. 1, no. 1 (2020): 108.
} 
bersama dengan membentuk kelompok- kelompok kecil untuk memudahkan mereka dalam belajar lewat bimbingan belajar. Sehingga anak dapat mengerjakan tugas dari guru, belajar bersama, saling berdiskusi serta anak dapat terus belajar dengan baik walaupun diterapkan system pembelajaran secara daring.

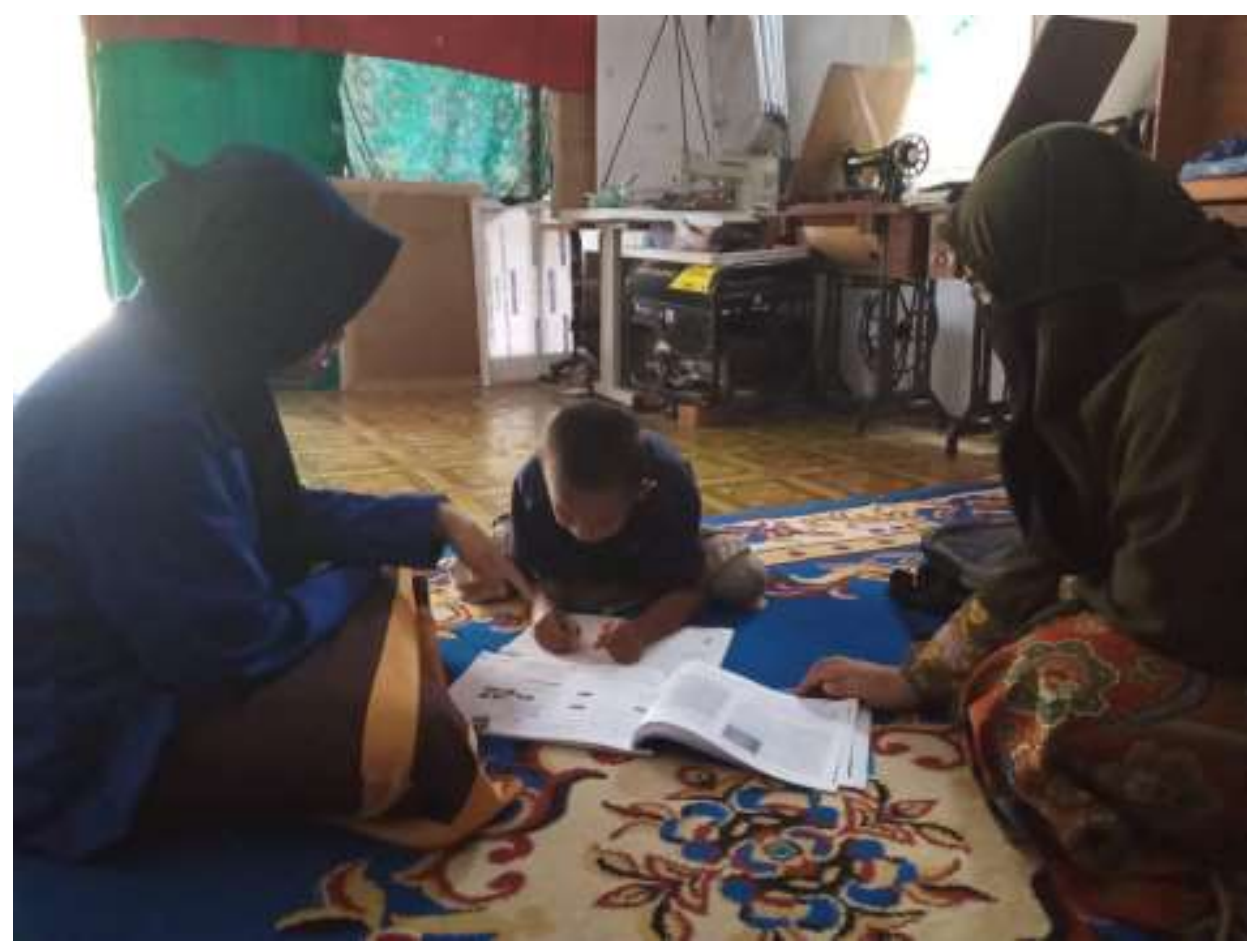

Photo Kegiatan bimbingan belajar KKN STIQ Amuntai

Adanya sistem pembelajaran daring yang ada saat ini membuat seringnya para guru memberikan tugas belajar terhadap anak sebagai tambahan pembelajaran secara system tatap muka atau langsung, selain itu dengan adanya pemberian tugas juga dapat memastikan bahwa materi pembelajaran yang disampaikan tersebut dapat dipahami oleh siswa. Dengan adanya pemberian tugas kepada siswa mmebuat kesulitan bagi anak dalam mengerjakan berbagai macam tugas tersebut terutama melalui sistem daring. Tugas yang diberikan terkadang lebih dari satu dan juga soalsoal yang diberikan sulit dipahami. Adapun hambatan yang anak sering alami adalah kurangnya pemahaman anak terhadap tugas yang diberikan oleh guru mereka dan bagaimana cara untuk menyelesaikan tugas tersebut. Dengan adanya bimbingan belajar ini kami sebagai pendamping mereka dalam belajar dapat membimbing, menjelaskan dan mengarahkan anak agar paham terhadap soal guru tersebur dan bisa menjawabnya dengan benar. selain itu anak sering diberikan tugas dari guru yang harus mereka kumpul ke sekolah setiap minggunya. Siswa terpaku pada tugas yang banyak tersebut dan kurang paham terhadap bahan materi yang disamapaikan oleh guru lewat online. kami membantu dengan memberikan tambahan pembelajaran dari berbagai sumber bahan materi yang relevan agar mereka lebih paham terhadap materi tersebut dan tidak hanya terpaku dengan berbagai macam tugas guru saja.

\section{Memfasilitasi Anak untuk Belajar}

Dengan berubahnya Sistem pendidikan dari tatap muka menjadi daring dari rumah pada pada masa pandemi ini banyak menimbulkan permasalahan baru terutama 
bagi siswa. Salah satu hal yang paling sering dikeluhkan oleh para siswa adalah kuota internet. Bagi siswa kuota internet sangat penting bagi mereka dalam penunjang dalam belajar, dengan adanya kouta internet mereka dapat mengakses internet dan mengunduh materi. Kantor Desa Keramat menyediakan Wifi gratis untuk masyarakat yang dapat diakses oleh semua orang terkhusus untuk anak-anak. Dengan adanya WiFi gratis anak-anak terbantu dalam menyelesaikan tugas sekolah terutama pada masa pandemi covid-19. Pembatasan penggunaan Wifi yang dilakukan oleh pihak desa sebagai upaya untuk mengantisipasi anak-anak dalam penggunakan hal-hal yang kurang bermanfaat. Dengan adanya bimbingan belajar yang diadakan oleh mahasiswa KKN dapat membantu meningkatkan semangat dan memberikan motivasi kepada anak-anak untuk lebih giat lagi menyelesaikan tugas yang diberikan oleh guru.

\section{KESIMPULAN}

Program belajar daring dari rumah dilakukan secara mandiri oleh para siswa di rumah mereka, dengan adanya kebijakan seperti ini mengharuskan orang tua perlu mempersiapkan pendidikan anak untuk mewujudkan cita-cita mereka. Dalam hal ini Desa Keramat memiliki banyak anak-anak yang bestatus sebagai siswa diharapkan dapat memperoleh pendidikan yang baik. Dengan adanya program bimbingan belajar dapat membantu para orang tua dalam membimbing dan membantu anak mereka dalam mengerjakan berbagai macam tugas dari sekolah yang telah diberikan oleh guru. Adapun harapan guru dan orangtua dengan adanya program bimbingan belajar yang diadakan dapat membantu mencapai kemajuan dalam dunia pendidikan khususnya anak-anak dari Desa Keramat.

\section{DAFTAR PUSTAKA}

Aisyah, Siti. Perkembangan Peserta Didik dan Bimbingan Belajar. Yogyakarta: Deepublish, 2015.

Aji Fatma Dewi, Wahyu. "Dampak Covid-19 terhadap Implementasi Pembelajaran Daring di Sekolah Dasar.” Edukatif: Jurnal Ilmu Pendidikan Vol. 2, no. 1 (2020).

Anggito, Albi, dan Johan Setiawan. Metodologi Penelitian Kualitatif. Jawa Barat: CV Jejak, 2018.

Anugrahana, Andri. "Hambatan, Solusi dan Harapan: Pembelajaran Daring Selama Masa Pandemi Covid-19 oleh Guru Sekolah Dasar." Scholaria: Jurnal Pendidikan dan Kebudayaan Vol. 10, no. 3 (2020): 282-89.

Hakim, Lukman Nul. "Ulasan Metodologi KUalitatif Wawancara terhadap Elit." Jurnal Aspirasi 04, no. 02 (2013).

Hamzah, Amir. Metode Penelitian Kepustakaan (Library Research) Kajian Filosofis, Teoritis dan Aplikatif. Malang: CV. Literasi Nusantara Abadi, 2019.

Handayani, Tri, Hariyani Nur Khasanah, dan Rolisda Yosintha. "Pendampingan Belajar di Rumah Bagi Siswa Sekolah Dasar Terdampak Covid-19." Abdipraja: Jurnal Pengabdian Kepada Masyarakat Vol. 1, no. 1 (2020).

Harahap, Nursapia. Penelitian Kualitatif. Sumatera Utara: Wal Ashri Publishing, 2020.

Hardani, et.al. Metode Penelitian Kualitatif dan Kuantitatif. Yogyakarta: CV Pustaka Ilmu, 2020. 
Hasanah, Hasyim. "Teknik-Teknik Observasi: Sebuah Alternatif Metode Pengumpulan Data Kualitatif Ilmu-ilmu Sosial.” Jurnal At-Taqaddum Vol. 8, no. 1 (2016).

Husein Batubara, Hamdan. Pembelajaran Berbasis Web dengan Moodle Versi 3.4. Yogyakarta: Deepublish, 2018.

Lorentya, Yulianti Kurnianingtyas. "Implementasi Strategi Pembelajaran Kooperatif Teknik Jingsaw untuk Meningkatkan Keaktifan Belajar Akutansi pada Siswa Kelas X Akuntansi 3 SMK Negeri Yogyakarta Tahun Ajaran 2011/2012.” Jurnal Pendidikan Akuntasi Indonesia Vol. X, no. No. 1 (2012).

Moleong, Lexy J. Metode Penelitian Kualitatif. Bandung: Remaja Rosdakarya, 2007.

Novita Fitriani, Dian. "Kajian Tentang Oral Dokument: Tinjauan Pada Gerakan Dokumentalis Baru." Visi Pustaka Vol. 20, no. No. 01 (2018).

Nugrahani, Farida. Metode Penelitian Kualitatif dalam Penelitian Pendidikan Bahasa. Surakarta, 2014.

Purwanto, et al, Agus. "Studi Eksploratif Dampak Pandemi COVID-19 terhadap Proses Pembelajaran Online di Sekolah Dasar." Journal of Education, Psychology and Counseling Vol. 2, no. 1 (2020).

Ritonga, Muhammad Nazir, dan Wahyuni. Pengembangan Model Pembelajaran Bahasa Arab Berbasis Teknologi Informasi dan Komunikasi dalam Dialektika Revolusi Industri 4.0. Yogyakarta: Deepublish, 2020.

Santoso, Agus, dan Yunni Rusmawati. "Pendampingan Belajar Siswa di Rumah Melalui Kegiatan Bimbingan Belajar di Desa Guci Karanggeneng Lamongan." Abdimas Berdaya: Jurnal Pengabdian Masyarakat Vol. 2, no. 2 (2019): 3643.

Satiyasih Rosali, Ely. “Aktifitas Pembelajaran Daring Pada Masa Pandemi Covid-19 di Jurusan Pendidikan Geografi Universitas Siliwangi Tasikmalaya." Geography Science Education Journal (GEOSEE) Vol. 1, no. 1 (2020).

Sugiarto, Eko. Menyusun Proposal Penelitian Kualitatif: Skripsi dan Tesis. Yogyakarta: Suaka Media, 2015.

Sugiyono. Sugiyono, Metode Penelitian Kuantitatif, Kualitatif dan R\&D. Bandung: Alfabeta, 2018.

Suhanadji, Rivo Nugroho, Mustakim, dan Wiwin Yulianingsih. "Keterlibatan Orangtua dalam Pendampingan Belajar Anak selama Masa Pandemi Covid19." Jurnal Obsesi: Jurnal Pendidikan Anak Usia Dini Vol. 5, no. 2 (2021): $1138-50$.

Suwandra, I Wayan. Metodologi Penelitian Kualitatif dalam Ilmu Sosial, Pendidikan Kebudayaan dan Keagamaan. Bandung: Nilacakra, 2018.

Wardani, Anita, dan Yulia Ayriza. "Analisis Kendala Orang Tua dalam Mendampingi Anak Belajar di Rumah pada Masa Pandemi Covid-19." Jurnal Obsesi: Jurnal Pendidikan Anak Usia Dini Vol. 5, no. 1 (2021): 772-82. 